\title{
Article \\ Effect of Microstructures on the Shear Strength of Larix kaempferi
}

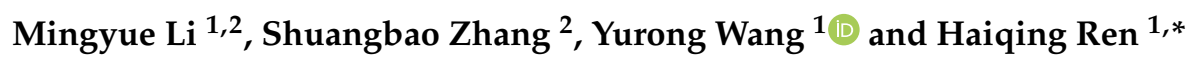 \\ 1 Research Institute of Wood Industry, Chinese Academy of Forestry, Beijing 100091, China; \\ limingyue@caf.ac.cn (M.L.); yurwang@caf.ac.cn (Y.W.) \\ 2 College of Materials Science and Technology, Beijing Forestry University, Beijing 100083, China; \\ shuangbaozhang@bjfu.edu.cn \\ * Correspondence: renhq@caf.ac.cn; Tel.: +86-(010)-6288-9460
}

check for

updates

Citation: Li, M.; Zhang, S.; Wang, Y.; Ren, H. Effect of Microstructures on the Shear Strength of Larix kaempferi. Forests 2021, 12, 830. https:// doi.org/10.3390/f12070830

Academic Editor: Geoffrey Daniel

Received: 17 May 2021

Accepted: 22 June 2021

Published: 24 June 2021

Publisher's Note: MDPI stays neutral with regard to jurisdictional claims in published maps and institutional affiliations.

Copyright: (c) 2021 by the authors. Licensee MDPI, Basel, Switzerland. This article is an open access article distributed under the terms and conditions of the Creative Commons Attribution (CC BY) license (https:// creativecommons.org/licenses/by/ $4.0 /)$.

\begin{abstract}
Shear strength is important for the application of Larix kaempferi (Lamb) Carr. The structural difference between earlywood and latewood of Larix kaempferi affects its mechanical properties, especially shear strength. The microstructures of earlywood and latewood in Larix kaempferi, however, are different. In this study, we investigated the shear strength and shear failure mode in the RL direction of 40 Larix kaempferi specimens. The results demonstrated that the initial crack appears in any location of a growth ring, whereas shear failure is concentrated in earlywood, as well as the junction between earlywood and latewood. The destruction of earlywood is the tear destruction, whereas when the destruction happened in the junction of earlywood and latewood, one to three earlywood cells usually adhered to latewood. At the cell wall level, the shear failure of earlywood was mostly observed in the direction of the microfibril angle (MFA). When the crack occurs in latewood, the destruction of latewood also occurs in the intercellular layer and preserves the complete morphology of tracheids. When destruction occurs in the wood ray, the ray cells detach intact from the tracheids. The failure mode is determined by the microstructure of earlywood and latewood. Our research suggests that the density, cell wall thickness, and MFA have significant differences between earlywood and latewood. The earlywood was found to have an MFA of $25.4^{\circ}$, a cell wall thickness of $6.36 \mu \mathrm{m}$, and a density of $0.39 \mathrm{~g} / \mathrm{cm}^{3}$. The MFA, cell wall thickness, and density of latewood density were $17.60^{\circ}, 12.37 \mu \mathrm{m}$, and $0.78 \mathrm{~g} / \mathrm{cm}^{3}$, respectively. However, there was no significant difference found in the crystallinity between the earlywood (43.97\%) and latewood (42.79\%). The correlation between the microstructures and shear strength showed that earlywood with a thin cell wall, large MFA, and low density had poor shear performance, while the latewood with a thicker tracheid, smaller MFA, and higher density had better shear performance. Therefore, when shear failure occurred, it occurred in earlywood. We thus deduced that the MFA, cell wall thickness, and density of earlywood synergically affect the shear strength in the RL direction of L. kaempferi.
\end{abstract}

Keywords: L. kaempferi; earlywood; latewood; fracture mode; microstructures

\section{Introduction}

L. kaempferi is a common afforestation tree species in northeast China. It was introduced to the country at the end of the 19th century and has since become an important timber species with an increased plantation area [1]. It has good mechanical propertiesi.e., it is uniform and stable, as well as having good natural durability [2]—so it can be used as a raw material in building materials and industrial materials [3]. A number of researchers have reported properties of L. kaempferi, including the bonding property [4], gene selection [5], mechanical property [6,7], relationship between growth and mechanics [8], microstructure [9], and so on. In a previous study, L. kaempferi was found to be prone to shear failure [10], which could restrict its utilization. As an engineering wood species, splintering is a consequence of timber's poor shear strength, which reduces the 
wood dimension and its strength [11]. When L. kaempferi is applied to cross laminated timber (the most commonly used building material) as the transverse layer, rolling shear failure often occurs under bending stress [12,13]. At the same time, shear strength is the main factor that affects the compressive strength of pin groove and the performance of the wood connection [14,15]. For longitudinal shear failure, shear failure in the RL direction is important. Therefore, it is necessary to study the longitudinal shear performance of $L$. kaempferi in the RL direction.

Wood is a natural, renewable, and composite material, consisting of cell arrays. The orientation of these cellular components and their arrangement determine the mechanical behavior of wood [16] (e.g., the difference in mechanical properties between earlywood and latewood) [17]. In terms of shear performance, Katri reported that the shear performance of mature heartwood is better than that of sapwood and juvenile wood in Larix sibirica [18]. In other reports, the mechanical properties of wood have been closely related to physical properties and microstructures. In Ulrich Müller's study, the longitudinal shear properties of wood were related to wood density, MFA, and lignin content [19] but not to arabinogalactan concentration [20]. As found in a study by Yukiko [7], partial compression stresses in the tangential loading direction increased when air-dried wood density increased. This increase occurred when the width of the annual rings decreased on average. In the Katri study, shear strength in sapwood was not correlated with density, radial diameter, or double wall thicknesses. For the wall, the wall-to-lumen ratio of earlywood increased the shear strength [11]. Another study showed that the higher absolute shear strength occurred when rays were oriented perpendicular. In this case, rays prevented shear-caused sliding of the growth rings by blocking them and acting as a "bolt" [21]. In addition, a positive correlation between wood crystallinity and stiffness has also been reported [22]. However, the relationship between crystallinity and shear strength has not yet been reported.

Due to the orthotropic characteristics of wood, the failure mode of wood has become a research focus. The failure mode of wood can be determined via the mechanical properties of wood structural units, the loading mode, and wood microstructure. Different tissues play different roles during wood fracture. In Ren's report, earlywood cells were determined to be prone to fracturing across the cell wall because of their thin walls and low strength [23]. Surveys, such as the one conducted by Gong [24], showed that wood damaged under tensile load caused the destruction of earlywood cells in transverse fracture cell walls and intra-cell wall cleavage, while the destruction modes of latewood cells were transverse fracture cell walls. The only cleavage between the intercellular layers occurred at the junction of earlywood and latewood. Studies conducted by Bodner came to the same conclusion [25-27]. The unique arrangement of rays caused cracks to spread along the edges of wood rays, leading to the formation of neat fractures [23]. The existence of pits on tracheids also caused special failure modes. According to Mott, during tensile failure of Picea asperata latewood, cracks typically occurred on the upper and lower edges of a bordered pit [28]. Most studies in the field of failure mode have only focused on shear strength in the TL direction, as well as bending, tensile strength, and compressive strength. However, there are few studies that focus on the failure mode of shear strength in the RL direction. Studies that have examined wood failure have shown that the failure mode was closely related to the microstructure of wood. Further research on the relationship between failure mode and microstructure is necessary.

Research on the cell wall level has become more important because it can clarify macroscopic differences in wood mechanics. Therefore, the aim of this study was to provide the failure mode for the shear failure of L. kaempferi in the RL direction, as well as to analyze the microstructures of earlywood and latewood and discuss the correlation of microstructures on the shear strength of L. kaempferi. The main focus was to discover the main factors that affect the shear strength in the RL direction based on the microstructure and fracture planes. 


\section{Materials and Methods}

\subsection{Material Preparation}

In this study, L. kaempferi, planted at a plantation in Liaoning Province, was selected as the material. Beams were stored in a climate chamber at $20{ }^{\circ} \mathrm{C}$ and $65 \%$ relative humidity until an equilibrium moisture content of approximately $12 \%$ was reached. The densities of the samples ranged between 0.36 and $0.58 \mathrm{~g} / \mathrm{cm}^{3}$.

\subsection{Shear Strength}

In total, 40 notched specimens as described in Section 2.1 were prepared in the RL system (Figure 1). The shear strength was measured according to GB/1937-91. The test was carried out at a uniform rate, and the test specimen was destroyed within 90-120 s. Before measurement, the number and width of the annual rings were measured on the transverse face of the butt end of the samples.

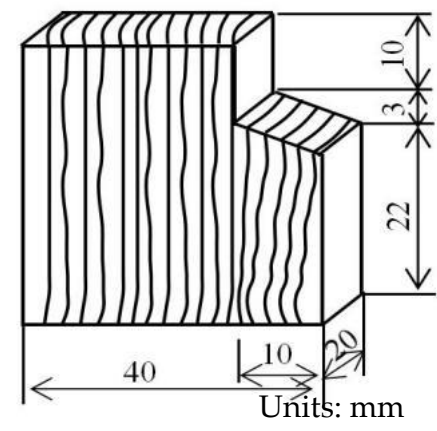

(a)

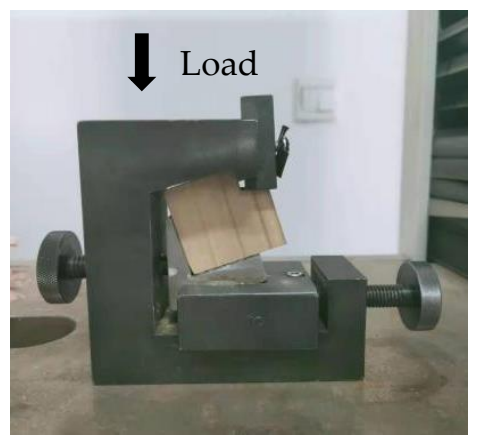

(b)

Figure 1. Schematic diagram of the shear specimen. (a) Dimensions and shapes of shear speci-mens. (b) Direction and position of load.

\subsection{Failure Mode}

First, the shear failure cross section was visually observed. The typical failure position was sawn into small specimens $(10 \mathrm{~mm} * 10 \mathrm{~mm} * 5 \mathrm{~mm})$ and coated with a thin layer of gold to analyze the failure mode of the cell wall under SEM. Micrographs were taken at 10 KV acceleration voltage using a Hitachi "S-4800" microscope (Tokyo, Japan).

To observe the anatomical structure of the damaged position, samples were transversely sectioned at a thickness of 10-15 $\mu \mathrm{m}$ and dehydrated through an alcohol series. Then, they were stained with safranine and observed using a ZEISS Imager A1 microscope (Jena, Germany).

\subsection{Determination of the Density}

\subsubsection{Determination of the Average Density of the Samples}

The air-dry density of the whole wood was measured according to the GB/T 19332009 method for the determination of the density of wood [29]. The samples reached an equilibrium moisture content at $20{ }^{\circ} \mathrm{C}$ and $65 \%$ relative humidity. Their weight and radial, tangential, and longitudinal dimensions were measured. Then, the samples were placed in an oven at $60^{\circ} \mathrm{C}$ and dried until constant mass was achieved $103{ }^{\circ} \mathrm{C}$. The weight and radial, tangential, and longitudinal size were measured, and the air-dry density was calculated. Then, it was converted into the air-dry density under the condition of $12 \%$ moisture content.

\subsubsection{Determination of the Density of Earlywood and Latewood}

In total, 20 samples $(50 \mathrm{~mm}$ (radial) $\times 50 \mathrm{~mm}$ (longitudinal) $\times 5 \mathrm{~mm}$ (tangential) $)$ were prepared for density measurements. The density of earlywood and latewood of larch was measured using a density profile measuring system DENSE-LAB X (D-31785, Electronic Wood Systems Gmbh, Hameln, Germany). 


\subsection{Microstructure Analysis of Earlywood and Latewood}

\subsubsection{Cell Wall Thickness Measurement}

In total, 10 samples were transversely sectioned at a thickness of 10-15 $\mu \mathrm{m}$, containing a complete annual ring and dehydrated through an alcohol series. Moreover, they were stained with safranine for photography and observed using a Leica DMLB light microscope, as well as an image analysis system. Further, 20 tracheid wall thicknesses were measured for each sample's earlywood and latewood.

\subsubsection{Crystallinity Measurement}

An X-ray diffractometer (PANalytical B.V, Almelo, Holland) was used to measure crystallite size and relative crystallinity. Measurements were performed with the selected $\mathrm{CuK} \alpha$ radiation $(\lambda=0.154 \mathrm{~nm}$, voltage $=40 \mathrm{kV}$, and current $=40 \mathrm{~mA})$. The step size was $0.02^{\circ}$ and the scanning speed was $4^{\circ} / \mathrm{min}$. The relative crystallinity was determined by fitting the theoretical intensity of crystalline cellulose onto reflections presented by Gaussian functions and an amorphous background to the measured intensity curve. The relative crystallinity index (CR) was determined as follows:

$$
C R=\frac{I_{t o t}-I_{\text {amo }}}{I_{\text {tot }}}
$$

where $I_{t o t}$ is the total experimental intensity and $I_{a m o}$ is the intensity of the amorphous background [30].

\subsubsection{MFA Determination}

An X-ray diffractometer (PANalytical B.V, Almelo, Holland) was used to measure the MFA of the samples using wood chips. The sample was rotated, and the intensity curve was measured as a function of the rotation angle, $\varphi$, with a step of $0.5^{\circ}$ and a measuring time of $180 \mathrm{~s}$ per point. A CuK $\alpha$ radiation source was used with $\lambda=0.154 \mathrm{~nm}$, voltage $=40 \mathrm{kV}$, and current $=40 \mathrm{~mA}$. The aperture of the incident beam was $2 \times 4 \mathrm{~mm}$. The mean MFA was determined according to the method developed by Cave [31], i.e., $0.6 \mathrm{~T}$, where $\mathrm{T}$ is an XRD parameter taken from the tangents drawn at the points of inflection [32].

\section{Results}

\subsection{Shear Test Results}

3.1.1. Shear Strength

The experimental results indicate that the average shear strength for the 40 shear samples was $4.14 \mathrm{MPa}$, the standard deviation was 0.92 , the average density of the samples was $0.427 \mathrm{~g} / \mathrm{cm}^{3}$, the standard deviation was 0.044 , the average number of rings of samples was 5.73, the maximum number of rings of samples was 8 , and the minimum number of rings of samples was 4 . The mean width of the rings where the shearing occurs was $7.44 \mathrm{~mm}$, and the standard deviation was 3.34. Additionally, the relationships between the shear strength, density, number of rings, and width of the ring where shear failure occurs are shown in Table 1.

Table 1. Correlation coefficient $r$ between shear strength, density, the number of tree rings, and the width of the shear ring.

\begin{tabular}{|c|c|c|c|c|}
\hline Indexes & Shear Strength & Density & Number of Rings & Width of the Ring \\
\hline Shear strength & 1 & & & \\
\hline Density & 0.51 & 1 & & \\
\hline Number of rings & 0.29 & 0.71 & 1 & \\
\hline Width of the ring & -0.015 & -0.615 & -0.734 & 1 \\
\hline
\end{tabular}

The behavior of the correlation coefficient suggested a weak correlation between density and shear strength, but no correlation was found between the shear strength and 
the number of rings on samples. Moreover, a weak correlation between the number of rings, density, and width of rings was found, indicating that the shear strength in the RL direction was less affected by the sample density and the number of tree rings. The number of tree rings somewhat affected the sample density. Yukiko studied the relationship between the compression strength and the annual ring width and density of Japanese larch, and the results showed that in the $\mathrm{T}$ direction, compression strength increased with increasing air-dried wood density and tended to increase with decreasing annual ring width [7]. Luostarinen studied the shear strength of Larix sibirica in the TL direction, and the results showed that the shear strength in the TL direction had no correlation with the density [11].

\subsubsection{Failure Mode}

Figure 2 shows the failure modes for 40 shear samples. Most specimens had gentle fractures without obvious zigzags. It was rare for cracks to propagate from one growth ring to another. If the failure began with earlywood, the crack propagated until it reached the boundary between earlywood and latewood, or when it ended at earlywood. The initial failure position occurred at the junction between earlywood and latewood. The crack did not laterally propagate and rather always extended at the junction of earlywood and latewood until the specimen was completely destroyed. In addition, the fracture surface of the specimen was not a complete surface. When the crack extended to the location of wood rays, the crack expanded along the wood rays to the junction in the earlywood and latewood of the next growth ring (Figure 3). However, this failure mode only appeared in 2 out of 40 samples in this study (samples 19 and 38). The destruction of the other samples occurred in a single growth ring. We do not fully understand the reasons behind the obtained result, but we have not ruled out that there was an incorrect sample texture.

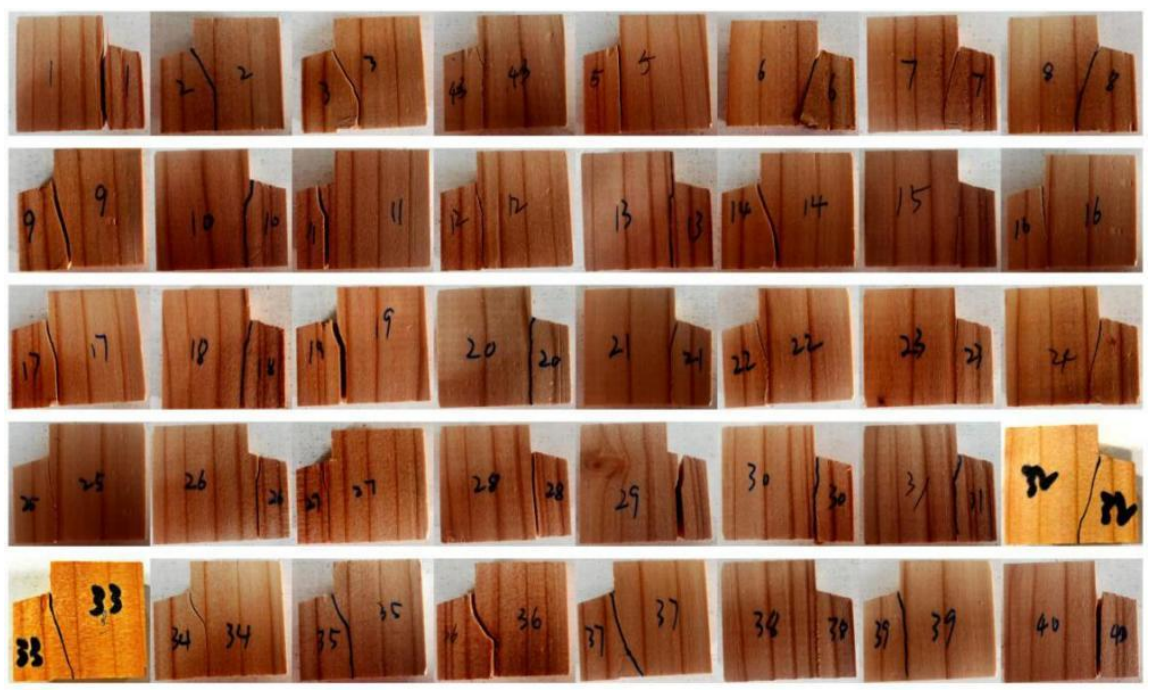

Figure 2. Failure mode of the shear failure of 40 samples.

\subsubsection{Microscopic Analysis of the Failure Location}

The cross section of the failure site was observed under a light microscope. The results indicated that the failure section of earlywood had more damaged cells and that the complete cell wall cannot be observed in Figure 4. The destruction of the junction between earlywood and latewood was not completely separated at the growth ring; usually, one to three earlywood cells adhered to the latewood (Figure 4a), which was similar to Ren's finding [23]. Similarly, the earlywood cells at the failure location were incomplete cells (Figure $4 \mathrm{a}, \mathrm{d}$ ). For the destruction of latewood, the cells still retained their cell morphology under a light microscope after destruction (Figure $4 \mathrm{~b}$ ). This indicated that under longitudinal shear stress, cells with thick walls were destroyed between $S_{1}$ and $S_{2}$, or in the 
intercellular layer. When the crack expanded to the wood ray site, there was no obvious ray cell fragment (Figure $4 \mathrm{c}$ ).

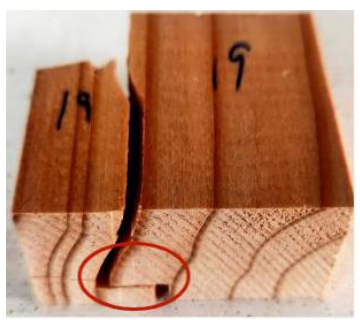

(a)

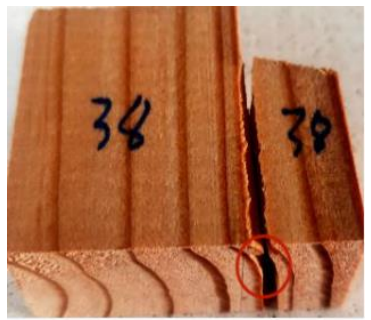

(b)

Figure 3. Failure patterns extending to different growth rings. (a) Sample 19 with wide rings. (b) Sample 38 with narrow rings.

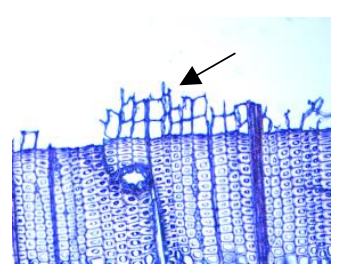

(a)

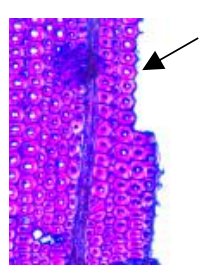

(b)

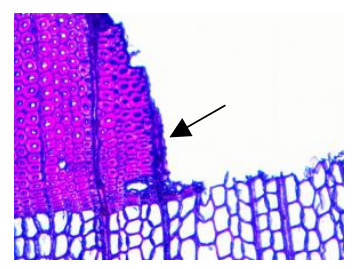

(c)

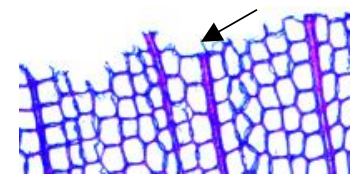

(d)

Figure 4. Failure mode under the light microscope. (a). The failure mode at the growth ring; (b). The failure mode at latewood; (c). The failure mode at wood ray; (d). The failure mode at earlywood.

The sectional morphology of wood was observed under SEM to specifically analyze the failure mode. The morphology of wood rays after stripping is shown in Figure 5a. Figure $5 b$ shows tracheids cell tearing along the MFA in the $S_{2}$ layer, wherein cracks can be observed from the failure surface in the earlywood position. When earlywood was destroyed, the cell destruction mode had a tearing failure (Figure 5c). Torn cell wall fragments that spiraled out of the fractured tracheids indicate a ductile character in the fracturing process. In Figure 5e, large MFA in the $S_{1}$ layer, as well as the brittle fracturing of latewood cells were shown. Cell damage in latewood in Figure $5 \mathrm{f}$ showed a difference from the tear damage of earlywood.

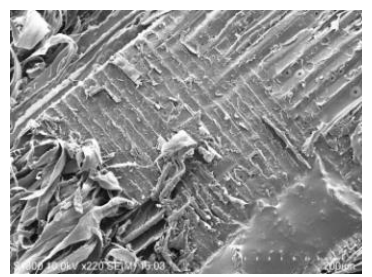

(a)

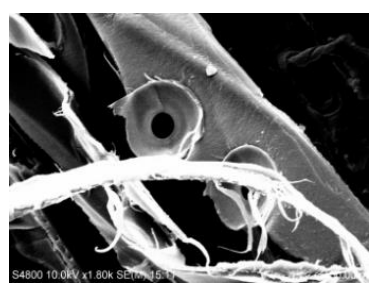

(d)

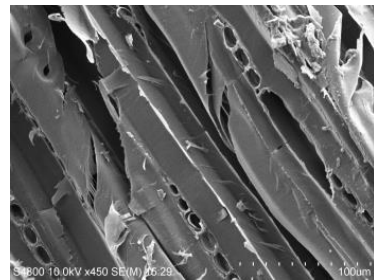

(b)

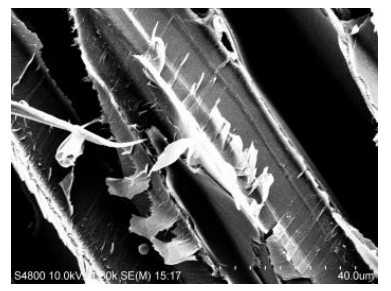

(e)

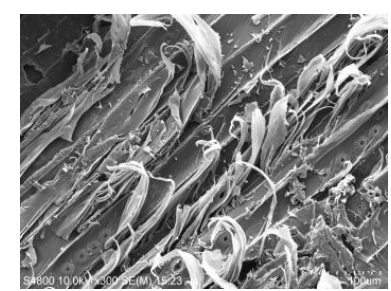

(c)

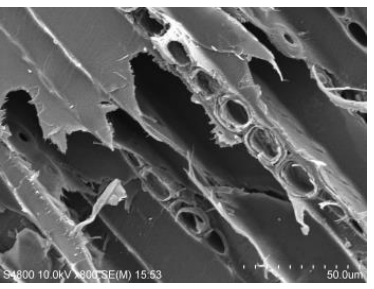

(f)

Figure 5. Section morphology under SEM. (a) the wood rays are separated from the tracheids altogether; (b) earlywood tracheid cracks; (c) tearing failure of earlywood tracheid; (d) pit in earlywood; (e) failure mode of tracheid separation in latewood; (f) failure mode of tracheid fracture in late wood. 


\subsection{Microstructure and Density of the Cell Wall of Earlywood and Latewood in L. kaempferi}

The above studies show that the structure of earlywood and latewood in larch determines the location and mode of shear failure; therefore, we examined the difference of density, crystallinity, and MFA between earlywood and latewood in L. kaempferi. As shown in Figure 6, the diffraction peaks of earlywood and latewood in L. kaempferi were similar, but the diffraction intensity was different.

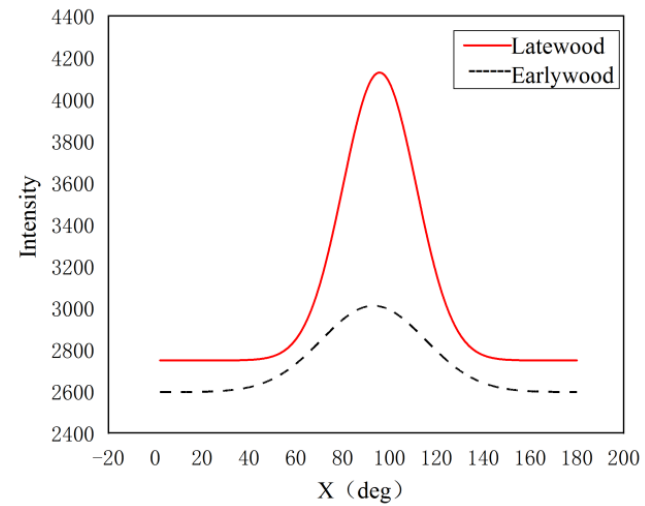

(a)

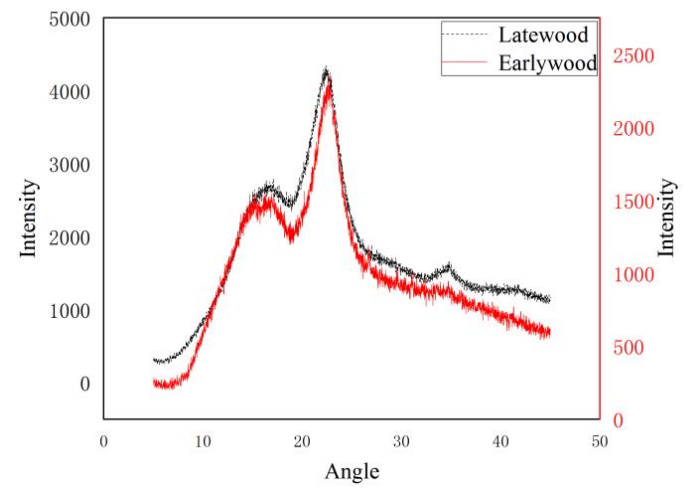

(b)

Figure 6. XRD of earlywood and latewood. (a) MFA; (b) crystallinity.

Table 2 shows the calculated values of density, MFA, cell wall thickness, and crystallinity of earlywood and latewood. There were significant differences in density, MFA, and cell wall thickness between earlywood and latewood, which was consistent with previous results [33]. The density and cell wall thickness of earlywood was significantly lower than that of latewood, and the MFA of earlywood was significantly larger than that of latewood. The cell wall thickness of latewood was about twice as thick as earlywood. However, unlike the difference in crystallinity between mature wood and juvenile wood [30], there was no significant difference in crystallinity between earlywood and latewood.

Table 2. Density, crystallinity, cell wall thickness, and MFA of earlywood and latewood.

\begin{tabular}{ccccc}
\hline Indexes & Density $\left(\mathbf{g} / \mathbf{c m}^{3}\right)$ & Crystallinity $\mathbf{( \% )}$ & MFA $\left(^{\circ}\right)$ & Cell Wall Thickness $(\boldsymbol{\mu m})$ \\
\hline Early wood & 0.39 & $43.97 \pm 0.06$ & $25.40 \pm 0.11$ & $6.36 \pm 0.25$ \\
Late wood & 0.78 & $42.79 \pm 0.03$ & $17.60 \pm 2.01$ & $12.37 \pm 0.95$ \\
$p$-value & $2.08 \times 10^{-8}$ & 0.15 & 0.0001 & 0.0001 \\
\hline
\end{tabular}

\section{Discussion}

The microstructure of the cell wall was a major factor in determining the destruction mode. In previous studies, fracture propagated in a stepwise manner and the earlywood zones fractured prior to the latewood zones [25]. In contrast with tensile and bending tests, the failure mode of shear in the RL direction is mainly concentrated in earlywood. Whatever direction the load is acting on, the earlywood is the weakest position. In the RL direction, the shear failure mode of earlywood was cell wall tearing, while the failure mode of latewood occurred in the intercellular layer and did not extend into the cell wall, which is the same as the damage under tensile load [24]. In Bodner's [27] report, wood samples stressed in tension showed intrawall fracture in latewood while earlywood tracheids showed longitudinal transwall failure similar to our results. As an orthotropic material, the structure of wood has a significant effect on the shear strength and shear failure mode. However, different from the action of tensile load, the shear failure in the RL direction rarely occurs in the wood rays and latewood. Therefore, neither the properties of wood rays nor latewood were the main factors affecting the shear strength in the RL direction in this study. The structural difference between earlywood and latewood in an annual ring was the main factor affecting the shear strength, shear failure zone, and failure mode. The 
density difference between earlywood and latewood was the main factor that impacted the shear failure location. The density of earlywood was obviously lower than that of latewood, and the cell wall of earlywood was thinner than that of latewood. Therefore, the shear strain mainly occurred in earlywood, which resulted in the final failure location to be mainly concentrated in earlywood. Consequently, when wood is subjected to shear strength in the RL direction, it is beneficial to consider earlywood strength when selecting materials. In other words, it is better to choose a tree species with a small difference in wood density and cell wall thickness between earlywood and latewood than to focus on the overall density. This is due to earlywood's structural weaknesses, which is the most vulnerable location. These characteristics of shear failure in the RL direction are, therefore, the most significant.

The difference between the MFA and cell wall thickness were the main factors that caused different failure modes in earlywood and latewood. The damage of earlywood is all cell damage, and the damage of latewood does not extend to the cell. The shear failure for earlywood was the tear damage of cells, where the tear ran mostly along the MFA direction, which is similar to Bodner's report [26]. In Gindl's shear test, the destruction of thick-walled cells usually occurred between cell walls, whereas the destruction of cell walls usually occurred in thinner cells [34]. This kind of fracture is common in cells with a large MFA [35]. In Qing's study, under the longitudinal shear force, stress was concentrated in the S2 layer [36], proving that the MFA in the S2 layer played an important role in shear strength in the RL direction. Due to different fracture surfaces, MFA may have less influence on shear strength compared with bending, tensile, and compressive strength [11]. On the contrary, this study shows that MFA plays an important role in shear strength. The failure mode at the wood ray position is because of a unique alignment of wood rays that causes cracks to propagate along the ray edges [23]. The slight difference in crystallinity between earlywood and latewood indicates that crystallinity has no effect on the shear properties between earlywood and latewood.

Combined with failure mode analysis, our experimental result corroborates the findings presented by Zink [37], i.e., the fracturing mode was dependent on cell wall thickness. In other words, intrawall shear fracture occurred between $S_{1}$ and $S_{2}$ in latewood tracheids, while in thinner-walled earlywood tracheids, the fracture mode was commonly a transwall structure. These structural differences between earlywood and latewood resulted in a regular failure pattern in the RL shear direction.

\section{Conclusions}

The number of rings in the samples and width of shear ring and sample average density had little effect on the shear strength in the RL direction. The structural difference between earlywood and latewood resulted in the shear failure mode of L. kaempferi in the RL direction. The failure mainly occurred in earlywood, and the damage of earlywood belonged to cell tearing. The density, MFA, and cell wall thickness of earlywood were significantly different from those of latewood. In view of the shear failure mode results, we concluded that the density, cell wall thickness, and MFA of the $S_{2}$ layer of earlywood might influence the shear strength and the shear failure mode.

Author Contributions: Conceptualization, H.R. and S.Z.; methodology, M.L. and H.R.; software, Y.W.; investigation, M.L.; resources, H.R. and M.L.; writing-review and editing, Y.W. and H.R.; supervision, H.R.; funding acquisition, H.R. All authors have read and agreed to the published version of the manuscript.

Funding: This research was funded by the National Natural Science Foundation (Project No. 31971596).

Data Availability Statement: The data used to support the findings of this study are available from the authors upon request.

Conflicts of Interest: The authors declare no conflict of interest. 


\section{References}

1. Ma, C.S.X. Larch genetic improvement and its future development in China. World For. Res. 2008, $21,58-63$.

2. Bei, Z. A brief introduction to the woods of five genera in the Pinaceae. China Timber 2016, 6, 27-31.

3. Xinting, X.; Sainan, Z.; Chuan, Z. Study on the mainly wood physical and mechanical properties of import lumber of Larix Kaempferi Carr. Wood Process. Mach. 2017, 28, 6-13.

4. Li, M.; Zhang, S.; Gong, Y.; Tian, Z.; Ren, H. Gluing Techniques on Bond Performance and Mechanical Properties of CrossLaminated Timber (CLT) Made from Larix kaempferi. Polymers 2021, 13, 733. [CrossRef]

5. Diao, S.; Hou, Y.; Xie, Y.; Sun, X. Age trends of genetic parameters, early selection and family by site interactions for growth traits in Larix kaempferi open-pollinated families. BMC Genet. 2016, 17, 104. [CrossRef]

6. Koizumi, A.; Kitagawa, M.; Hirai, T. Effects of growth ring parameters on mechanical properties of Japanese larch (Larix kaempferi) from various provenances. Eurasian J. For. Res. 2005, 8, 85-90.

7. Ishikura, Y.; Matsumoto, K.; Ohashi, Y. Radial variation in partial compression properties perpendicular to the grain of Japanese larch (Larix kaempferi). J. Wood Sci. 2012, 58, 399-407. [CrossRef]

8. Zhu, J.; Nakano, T.; Hirakawa, Y. Effect of growth on wood properties for Japanese larch (Larix kaempferi) Differences of annual ring structure between corewood and outerwood. Jpn. Wood Res. Soc. 1998, 44, 392-396. [CrossRef]

9. Takimoto, H.; Yasue, K.; Tokumoto, M.; Takeda, T.; Nakano, T. Within Annual Ring and Pith-to-bark Variations of the Microfibril Angle in the S2 Layer of Tracheid Walls in 106 year old Plantation of Japanese Larch. MOKUZAI GAKKAISHI 2013, 59, 121-127. [CrossRef]

10. Lei, C.; Zhongfeng, Z.; Dan, Z.; Guojing, H.; Jianong, C. Experimental research on fatigue behavior of larch glulam beams. J. Build. Struct. 2016, 37, 27-35.

11. Luostarinen, K.; Heräjärvi, H. Relationship between anatomy and shear strength in wood of Larix sibirica. Holzforschung 2018, 72, 1001-1006. [CrossRef]

12. Ehrhart, T.; Brandner, R. Rolling shear: Test configurations and properties of some European soft- and hardwood species. Eng. Struct. 2018, 172, 554-572. [CrossRef]

13. Gong, Y.C.; Xu, J.H.; Wu, G.F. Interlamination Shear Properties of Cross-laminated Timber Made from Domestic Japanese Larch in China. China Wood Ind. 2018, 32, 6-9.

14. Ke-Fu, W. New Type Connection of Wood Frame and Their Influence to the Performace of Structures. Master's Thesis, Southeast University, Nanjing, China, 2014.

15. Grekin, M.; Surini, T. Shear strength and perpendicular-to-grain tensile strength of defect-free Scots pine wood from mature stands in Finland and Sweden. Wood Sci. Technol. 2007, 42, 75-91. [CrossRef]

16. Jeong, G.Y.; Park, M.J. Evaluate orthotropic properties of wood using digital image correlation. Constr. Build. Mater. 2016, 113, 864-869. [CrossRef]

17. Büyüksarı, Ü.; As, N.; Dündar, T. Mechanical Properties of Earlywood and Latewood Sectionsof Scots Pine Wood. Bioresources 2017, 12, 4004-4012.

18. Luostarinen, K.; Heräjärvi, H. Dependence of shear strength on wood properties in cultivated Larix sibirica. Wood Mater. Sci. Eng. 2011, 6, 177-184. [CrossRef]

19. Müller, U.; Sretenovic, A.; Gindl, W.; Teischinger, A. Longitudinal shear properties of European larch wood related to cell-wall structure. Wood Fiber Sci. 2004, 36, 143-151.

20. Luostarinen, K.; Heräjärvi, H. Relation of arabinogalactans to density, growth rate and shear strength in wood of cultivated Siberian larch. Eur. J. Wood Wood Prod. 2012, 71, 29-36. [CrossRef]

21. Longui, E.L.; Pires, G.T.; Ballarin, A.W.; Machado, J.A.R. Shear strength parallel to grain with distinct ray orientation on four Brazilian wood species. Eur. J. Wood Wood Prod. 2016, 75, 663-665. [CrossRef]

22. Fujimoto, T.; Yamamoto, H.; Tsuchikawa, S. Estimation of Wood Stiffness and Strength Properties of Hybrid Larch by NearInfrared Spectroscopy. Appl. Spectrosc. 2007, 61, 882-888. [CrossRef] [PubMed]

23. Ning, R. The Research on the Influence of Wood Microstructure to Fracture. Master's Thesis, Northeast Forestry University, Harbin, China, 2007.

24. Cuizhi, G.; Yixing, L.; Yongzhi, C.; Haipeng, Y.; Ning, R. Detection of the Process of Wood Fracture In-Situ Test by Environmental Scanning Electron Microscope. J. Northeast. For. Univ. 2007, 35, 7-9.

25. Bodner, J.; Schlag, M.G.; Grüll, G. Fracture Initiation and Progress in Wood Specimens Stressed in Tension. Part I. Clear Wood Specimens Stressed Parallel to the Grain. Holzforschung 1997, 51, 479-484. [CrossRef]

26. Bodner, J.; Schlag, M.G.; Grüll, G. Fracture Initiation and Progress in Wood Specimens Stressed in Tension. Part II. Compression Wood Specimens Stressed Parallel to the Grain. Holzforschung 1997, 51, 571-576. [CrossRef]

27. Bodner, J.; Schlag, M.G.; Grüll, G. Fracture Initiation and Progress in Wood Specimens Stressed in Tension. Part III. Clear Wood Specimens with Various Slopes of Grain. Holzforschung 1998, 52, 95-101. [CrossRef]

28. Mott, L. Micromechanical Properties and Fracture Mechanisms of Single Wood Pulp Fibers. Master's Thesis, University of Maine, Orono, ME, USA, 1995.

29. Beijing SPoC. GBT 1933-2009 Method for Determination of the Density of Wood; Standardization Administraton of China and General Administration of Quality Supervision, Inspection and Quarantine of the People's: Beijing, China, 2009. 
30. Andersson, S.; Serimaa, R.; Paakkari, T.; Saranp, Ä.Ä.P.; Pesonen, E. Crystallinity of wood and the size of cellulose crystallites in Norway spruce (Picea abies). J. Wood Sci. 2003, 49, 531-537. [CrossRef]

31. Cave, I.D. Theory_of_X-ray_measurement_of_microfibril_angle_in_wood. Wood Sci. Technol. 1997, 31, 9.

32. Seppo Andersson, R.S.; Torkkeli, M.; Paakkari, T.; Saranpfifi, P.; Pesonen, E. Microfibril angle of Norway spruce [Picea abies (L.) Karst.] compression wood: Comparison of measurin. J. Wood Sci. 2000, 46, 343-349. [CrossRef]

33. Shunxing, M. Studies on Genetic Variation and Early Selection of Japanese Larch Clones. Master's Thesis, Henan Agricultural University, Zhengzhou, China, 2006.

34. Wolfgang Gindl, A.T. Comparison of the TL-Shear Strength of Normal and Compression Wood of European Larch. Holzforschung 2003, 57, 421-426. [CrossRef]

35. Stanzl-Tschegg, S.E. Microstructure and fracture mechanical response of wood. Int. J. Fract. 2006, 139, 495-508. [CrossRef]

36. Qing, H.; Mishnaevsky, L. 3D hierarchical computational model of wood as a cellular material with fibril reinforced, heterogeneous multiple layers. Mech. Mater. 2009, 41, 1034-1049. [CrossRef]

37. Zink, A.G.; Pellicane, P.J.; Shuler, C.E. Ultrastructural analysis of softwood fracture surfaces. Wood Sci. Technol. 1994, 28, 329-338. [CrossRef] 